\title{
ANALYSIS OF USER EXPERIENCE RESOURCE PLANNING WITH USER EXPERIENCE QUESTIONNAIRE FRAMEWORK (CASE STUDY: UNIVERSITAS MULTIMEDIA NUSANTARA)
}

\author{
Andrei Ferdinan Bayu CKa ${ }^{a}$, Johan Setiawan ${ }^{b}$ \\ a, b Universitas Multimedia Nusantara, Jakarta, Indonesia
}

\begin{abstract}
Objective - To be able to find out how the level of influence of user experience using the 6 aspect UEQ factor can significantly or not affect the ERP system used at Universitas Multimedia Nusantara.

Methodology - This research uses a quantitative method by distributing surveys to 16 respondents in 3 departments of Universitas Multimedia Nusantara and processing them through the UEQ Framework.

Findings - The research found that the measurement level results obtained were based on the mean and benchmark user experience data from 6 UEQ scales from the highest to the lowest value level. Dependability was in the (Excellent) category, Stimulation was in the (Excellent) category, Novelty was in the (Excellent) category, Perspicuity is in the (Good) category, Attractiveness is in the (Good) category, and Efficiency is in the (Good) category and partially or completely can have a significant $61 \%$ influence on the use of modules in the ERP system at Universitas Multimedia Nusantara.

Novelty - The research can be used as a reference in order to provide benefits for universities, which are expected to be able to provide input, information, and assist universities in recommending ERP systems that must be evaluated or further optimized..

Keywords: ERP (Enterprise Resource Planning), UEQ (User Experience Questionnaire), Quantitative, SPSS.

JEL Classification: I21, L25, L31

Article Info: Received July 2021; Revised August 2021; Accepted August 2021

Article Correspondence: andrei@student.umn.ac.id ${ }^{\mathrm{a}}$, johan@umn.ac.id ${ }^{\mathrm{b}}$

Recommended Citation: CK and Setiawan (2021). Analysis of User Experience Resource Planning with User Experience Questionnaire Framework (Case Study: Universitas Multimedia Nusantara). Journal of Multidisciplinary Issues, 1 (2), 42-61.
\end{abstract}

\section{INTRODUCTION}

ERP is a compilation of internal resources as a "framework for organizing, defining, and standardizing the business processes needed to effectively plan and control the organization so that the organization can use its internal knowledge to seek external benefits.(Jacobs \& Weston, 2007).

The ERP system is intended as a foundation for the company with the achievement of a common goal that can regulate and automate information systems in internal processes and terms of human resource functions, production, logistics, accounting, distribution, finance contained within the company. The existence of communication and information technology as well as the data needed by the company can be found without requiring a long time (James A. O'Brien, 2007). The refusal to use the system in the use of an ERP system (new system) is one of the failure factors for ERP system implementation that should be observed by universities and companies. Low user understanding can make users simply forced to use it and not adapted to a qualified use of the ERP system (Dewi \& Asriani, 2019). ERP systems are becoming essential for all types of organizations today. However, in addition to implementing an expensive ERP system, organizations must also measure and see whether the ERP system implemented will function properly or not. Therefore, user satisfaction also needs to be used as a benchmark in the ERP system implementation process (Kulathunga \& Krishantha, 2019).

In addition, user satisfaction is a factor of one of the keys to success in ERP implementation, where ERP can be seen as a software package that can support users to complete their work efficiently and effectively 
and user satisfaction can be used as a determinant of success (Bruun \& Stage, 2015). The report on the survey results in (Panorama Consulting Solutions, 2019) on user experience and satisfaction related to how many failures was experienced in the ERP implementation process in 2019-2021 can be concluded that:

- In $201822 \%$ of failures in ERP implementation were influenced by factors from user experience and satisfaction. Then the influence increased by $26 \%$ in 2019 and in 2020 the influence decreased by $7 \% 2020$.

There are several studies related to the implementation of ERP systems, failures can occur not only due to errors during software installation but mostly due to mistakes made by companies or universities to establish an accurate system, to handle the needs and business problems of companies or universities. the height. The refusal to use the system in the use of an ERP system (new system) is one of the failure factors for ERP system implementation that should be observed by universities and companies. Low user understanding can make users only forced to use it and not adapted to a qualified use of the ERP system.

In a previous study entitled "User Satisfaction Factors of ERP Systems: The Case of a Manufacturing Company in Sri Lanka". (2019). Several backgrounds can be used as benchmarks for the user experience of the ERP system in the research model, namely:

- IT user background.

- System accuracy.

- Ease of use of the system.

- System timeliness (input-output system)

In this study, using the McDelone \& McLean research model in order to find a strong relationship on the critical success factors that affect ERP system user satisfaction which will then lead to a successful and effective ERP system usage experience.

This research has a difference from previous research, because in this study the User Experience Questionnaire (UEQ) Framework was used with the help of SPSS software version 25 in measuring the level of user experience with the ERP PeopleSoft Oracle Campus Solution system using 6 aspects contained in the UEQ Framework.

Based on the results of the research, it can be concluded that in addition to the importance of the ERP implementation process in a company or university, there is also an influence on the user experience of the system as the key to ERP implementation success in order to minimize failures in the ERP system process. Therefore, it was decided to make an analysis of the ERP user experience using the Framework User Experience Questionnaire (UEQ) method on 3 modules in the ERP PeopleSoft Oracle Campus Solution, namely the Student Record, Academic Advisement and Student Financial modules by using a factor of 6 aspects in the User Experience Questionnaire to be able to find out how the influence of user experience and the overall average (mean) and benchmark data using a factor of 6 aspects of UEQ can significantly or not affect the ERP system used at Universitas Multimedia Nusantara.

\section{LITERATURE REVIEW}

\section{ERP Software System}

ERP system is a foundation contained in e-business technology that can link work structures in the form of transactions that exist in various parts of the world through links to sales management processing, inventory, financial control, and distribution and production planning. (Wallace \& Kremzar, 2001).

ERP is considered to have advantages in this regard such as opening up opportunities for implementing a single set of resource planning tools across the enterprise, providing real-time integration of sales, production operations, and finance data, as well as linking customer and product supplier chain resource planning approaches, plus ERP has a variety of software that has been widely used in various aspects. 


\section{Oracle Corporation}

Oracle Corporation is one of many ERP companies that are developing their business in the aspects of Database Management systems, Database Software, Enterprise Resource Planning, Customer Relationship, and Supply Chain Management. Oracle Corporation was founded in Redwood City, California in 1977 by 3 programmers named Larry Ellison, Bob Miner, and Ed Oates who served as CEO. Oracle Corporation is the first ERP company to prepare by providing a database system that can be used for conventional policies. In 2007 Oracle Corporation employed 68,236 workers.

The Oracle ERP system has special features that can be synchronized with a focus on e-business that can focus on multiple professionally managed internet servers. The technology contained in the system also consolidates and can distribute data or information into a database through a global network (Rajesh Kumar, 2019). The internet server contained in the Oracle ERP allows users to connect to all parts of their department by using the access provided by the ERP system. The easy and fast implementation process and the longer-lasting software life make the system usable by thousands of users with less operational costs.

Quoted from Oracle Corporation's Wikipedia source that PeopleSoft is an ERP system development company whose products have been widely used by various companies and educational institutions around the world. With the success of Oracle in acquiring PeopleSoft, it further expands and adds to the diversity of types of Oracle products (databases and applications) including the package from PeopleSoft, namely Oracle PeopleSoft Enterprise Application. Oracle PeopleSoft Enterprise Application is an ERP application system designed to provide solutions to improve performance within companies and universities by supporting complex industrial and business needs (O’Regan, 2015).

The easy use of PeopleSoft with the availability of integrated features found in web services is intended so that the system on the application can run flexibly and smoothly. In this study, PeopleSoft Oracle Campus Solution was chosen to be the object of research because in order to know whether there is a significant effect given by the existence of the PeopleSoft Oracle Campus Solution system on its users.

\section{PeopleSoft Oracle Campus Solutions}

PeopleSoft is one of the companies that provide solutions for Human Resource Management System which includes Supply Chain Management, Financial Management, Human Capital Management, Supplier Relations Management, and Enterprise Management as well as providing solutions for universities such as Campus Solution. In (PeopleSoft, 2012) PeopleSoft Oracle Campus Solution has several modules in it such as:

1. PeopleSoft Campus Community. The module can enable users to maintain and manage basic information about people and organizations of interest to the college. Every application in campus solutions relies on data that includes the name, address, and ID of an individual or organization (Oracle PeopleSoft, 2015).

2. PeopleSoft Recruiting and Admissions. The module is used to manage the admissions process within the college by managing recruiters and tracking prospects and applicants. The admissions office can empower prospective students through application systems offered with recruitment and admissions including automated processes such as evaluation of applications, loading of external test scores, recruitment category assignments, loading of applications from test score data, and loading of academic transcripts using the PeopleSoft EDI Manager tool. System integration with Academic Advisement, Campus Community, Financial Aid, Student Financial, and Student Records can reduce repetitive data input and improve the ease of communication in various departments within the university. For example, when applicants enter matriculation, their records automatically appear in student records(PeopleSoft Campus Solutions 9. 0: Recruiting and Admissions, 2014).

3. PeopleSoft Student Records. This module allows users to enter, track and process all academic information. PeopleSoft minimizes repetitive data entry to allow users to gain maximum control over student records (class schedules, programs, plans, and student sub plans) (Oracle PeopleSoft, 2015). 
4. PeopleSoft Gradebook. This module is a grouping of high-level assignments that can help users to monitor classwork and grades and facilitate communication between instructors and students such as quizzes, essays, and homework (Oracle PeopleSoft, 2015).

5. PeopleSoft Academic Advisement is an application that is included in the campus solution that is used to track the requirements and policies that must be met by students to graduate. When a student has gone through the process to get to graduation. Academic advisement analyzes the lessons that have been taken by both successful and unsuccessful students and ascertains what requirements still need to be met (Oracle PeopleSoft, 2015).

6. PeopleSoft Financial Aid. This module provides a flexible system for managing financial aid operations within an institution or organization. This system is used to guide users through need calculation, budget, disbursement, loan processing, and tracking data. Financial aid helps users process and track loan applications under the Federal Family Educational Loan Program (FFELP) together with state and university loan programs more efficiently and effectively (Oracle PeopleSoft, 2015).

7. PeopleSoft Student Finance. This module is a system for colleges to manage accounts receivable, billing, collection, and student cash. Using student finance, staff and students can quickly find and use the financial information they need to make important decisions. Student finance receives information from almost all fields within the campus solution (Oracle PeopleSoft, 2015).

8. PeopleSoft Contributor Relations. This module can be a comprehensive solution that can help professional contributor relationships to optimize strategic planning and decision making. This feature is integrated with other PeopleSoft in campus solutions, financial, and human resources (Oracle PeopleSoft, 2015). By using contributor relations, users can implement a strategic plan to handle and manage the components contained in this feature.

9. PeopleSoft Self Service. This module brings together many transactions into a single entity. Users can use the self-service page to provide system access to students, applicants, alumni, faculty, visitors, and other users and allow them to perform various service transactions within the selfservice. (Service, 2021).

Based on the various modules in the PeopleSoft Oracle Campus Solution that have been described, 3 modules out of a total of 9 modules contained in the PeopleSoft Oracle Campus Solution have been determined, namely: the first module is Student Record, the second is Academic Advisement and the third is Student Financial as research material. knowing or measuring to what extent the modules used can be a solution for universities to provide safe and comfortable access to financial and learning systems with an integrated system through the 6 scales contained in the User Experience Questionnaire (UEQ) Framework. User experience certainly has a big role in using a product as it is easy or difficult for a product to be used to achieve its goals.

\section{User Experience (UX)}

User Experience (UX) or can also be referred to as user experience is the understanding, response, and response of a person to the use of a system, product, or service (user comfort). User Experience is built on a principle where the public has a level of power in determining their satisfaction (customer rule) (Hendradewa, 2017).

The level of convenience of interaction in the user experience which includes systems, services, and features will below if there is no intended target who can understand the comfort and satisfaction of a product. With the continuous development of the mobile and digital world, making the user experience more multidimensional and complicated, it is easy for someone to access the website from various devices. Accessing a website via a desktop will be different when accessing a website via a smartphone because the experience on a device will be different from other devices (Farida, 2016). To make it easier and more efficient, the User Experience Questionnaire (UEQ) Framework is used to measure User Experience (UX) in a system. 


\section{User Experience Questionnaire (UEQ}

The User Experience Questionnaire (UEQ) is a tool used to assist in processing and processing data through surveys by linking it to user experience to make it easier to implement, valid and reliable and can be used to meet data from other evaluation methods by conducting quality assessments. done subjectively (Laugwitz et al., 2008).

The User Experience Questionnaire (UEQ) is sometimes used as a component of usability testing to combine quantitative data about user experience responses to a product. The main purpose of using the User Experience Questionnaire (UEQ) method is to obtain a quick and precise evaluation of the user experience of an interactive product (Schrepp et al., 2017). The User Experience Questionnaire (UEQ) has a pattern in the questionnaire that can help user reactions directly express attitudes, impressions, and feelings that arise when user interactions occur with a product. In (Laugwitz et al., 2008) the User Experience Questionnaire (UEQ) has 6 scales which are divided into 26 detailed statements as follows:

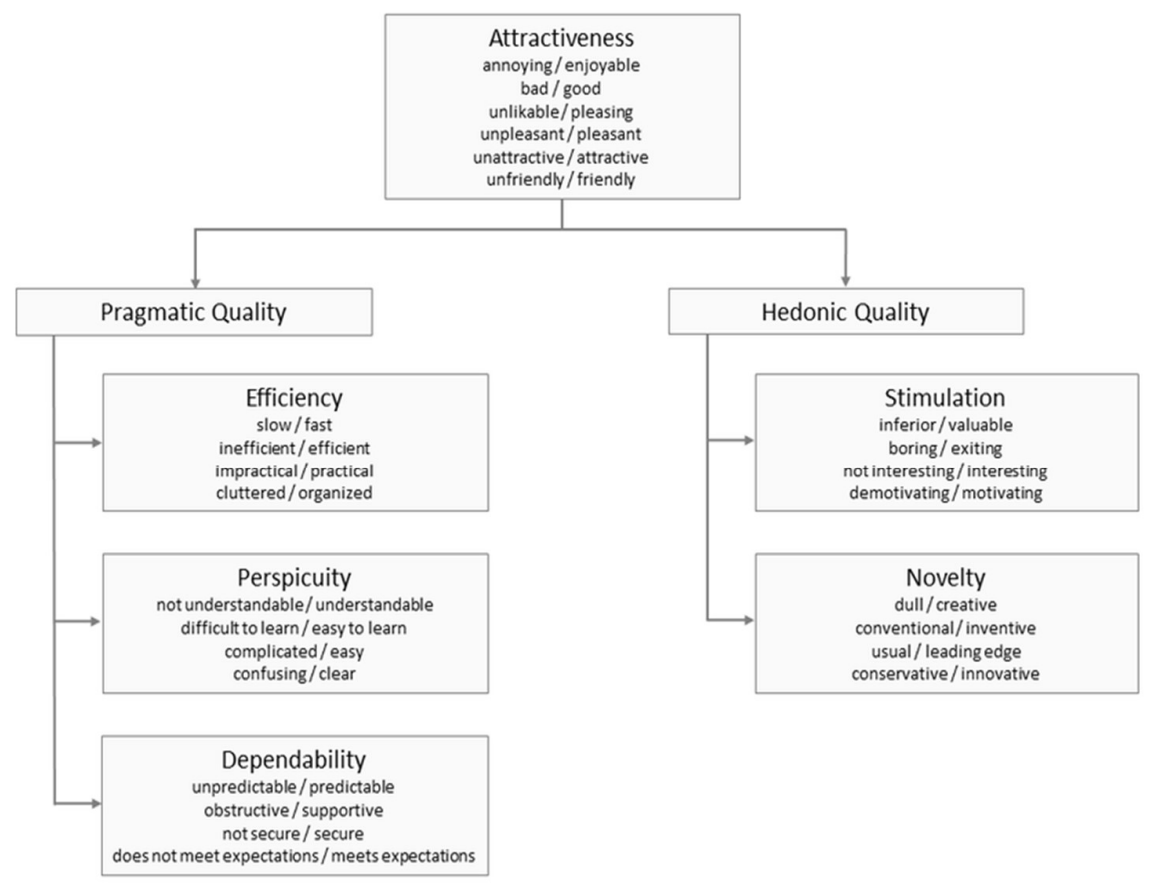

Figure 1. UEQ Scale Arrangement

- Attractiveness. How much attractiveness about the system as a whole, is a system liked or not by the users? For example: bad or good, troublesome or fun.

- Efficiency. Can the task be completed by the user precisely and accurately? For example: slow or fast, messy or organized.

- Perspicuity. How easy is the system to identify? How to learn to use the system easily? For example: incomprehensible or easy to understand, confusing or clear.

- Dependability. Can users feel control over an interaction? For example: not safe or secure, not as predicted or as predicted.

- Stimulation. Is the product attractive and motivating? For example: less useful or useful, not interesting or interesting.

- Novelty. Is the product creative or innovative? Does the product interest users? For example: not creative or creative, conservative or innovative. 


\section{Stages of Using UEQ}

According to (Schrepp, 2019) 3 stages must be passed in calculating using the User Experience Questionnaire Framework, namely:

1. Compile a list of questions. It can be seen in Figure 2 below that there is an arrangement of the list of questions contained in the UEQ Framework. The structure of the questions consists of 26 question components with 7 scales. With this list of questions, it is possible to collect quantitative data from respondents who have filled out the questionnaire.

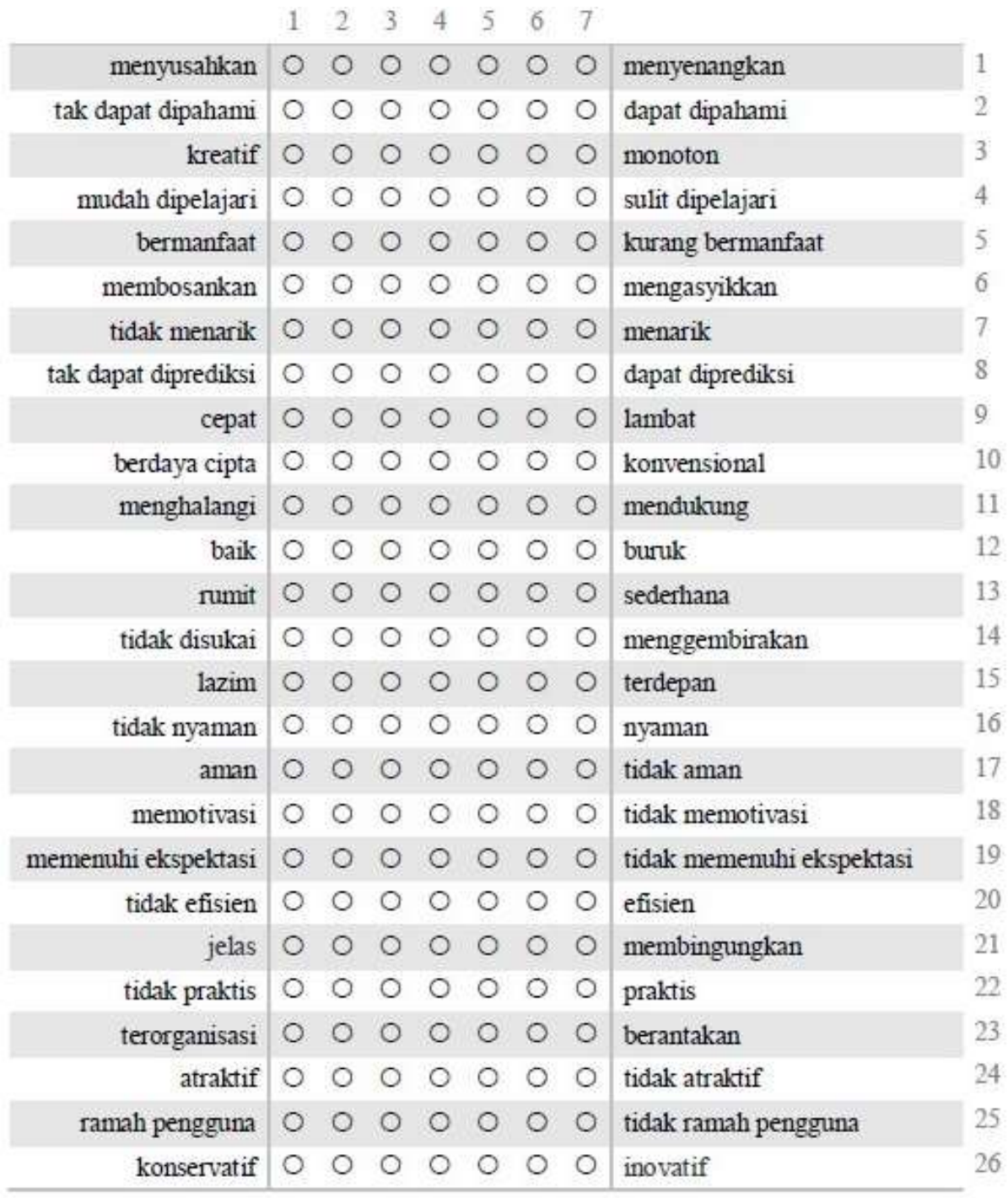

Figure 2. User Experience Questionnaire (Indonesian Version)

2. Using Data Analysis Tools (Excel). To obtain the results of the data on the questionnaire, then the calculations are carried out by downloading the excel template through the website http://www.ueq-online.org/ using data analysis tools (excel) by entering the data results from the questionnaire into excel. Numbers that can be entered are 1-7 with a maximum number of 1000 respondents. 
3. Get a conclusion. After calculating using data analysis tools (excel) it can be seen that the description in the form of data visualization from online questionnaires that have been completed by respondents obtained from the results of calculations through data analysis tools (excel).

\section{Research Flow}

In this research, the User Experience Questionnaire (UEQ) Framework was used to process data to obtain a conclusion from the research conducted. Below are the stages that will be carried out in the research:

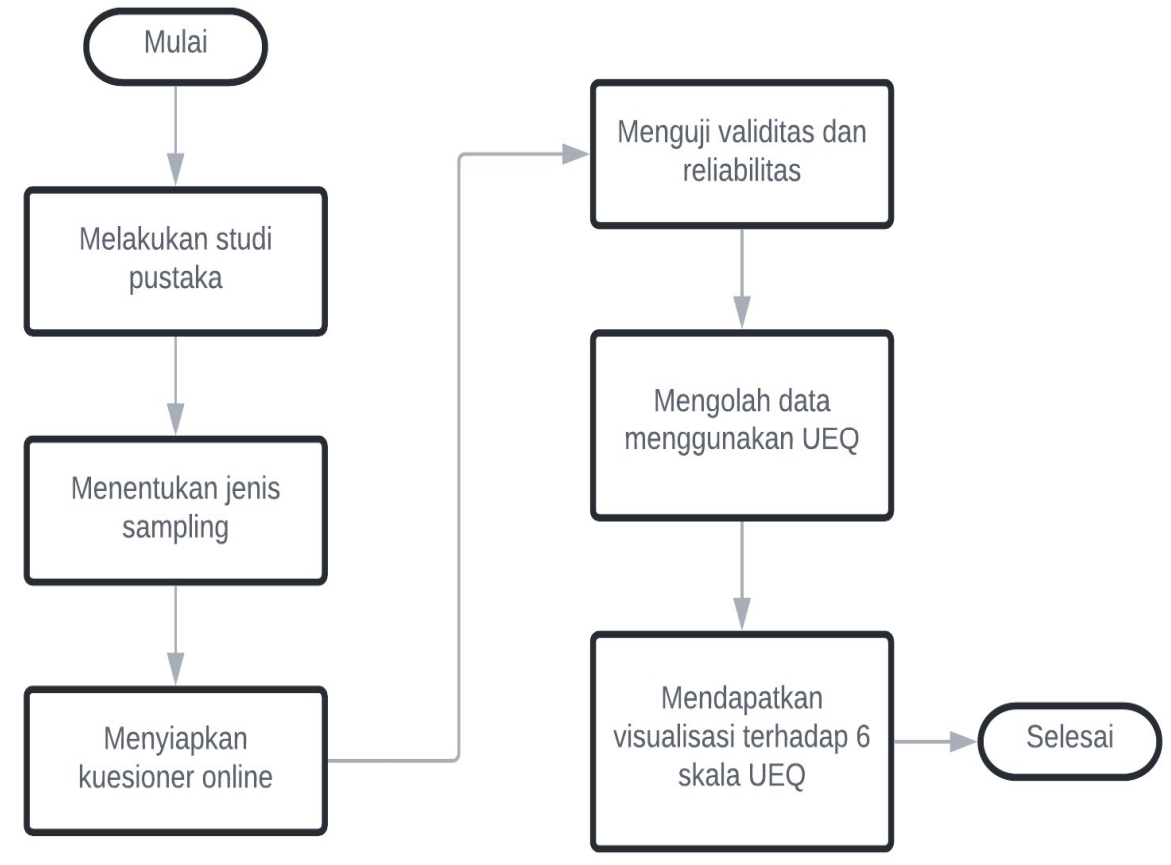

Figure 3. Research Flow

At the initial stage, the search for the data that you want to research is carried out through a literature study by studying various articles, journals, books, or reports related to the problem to be solved. This activity was carried out to find out if there was a relationship between user backgrounds from the PeopleSoft Oracle Campus Solution ERP system and the modules used.

Furthermore, several questions are made in the form of a questionnaire that is needed to collect the data needed in this study. After that, do an analysis of the system by looking for the types of methods you want to use based on sources from previous research that has been done. The User Experience Questionnaire (UEQ) Framework was chosen as the user experience experiment method on the system because from the sources of journals and articles it can be known and obtained information that the User Experience Questionnaire (UEQ) Framework can be used to evaluate company and university systems based on their user experience. After obtaining the information contained in the User Experience Questionnaire (UEQ) Framework, then determining the benchmarks (criteria) that will be used for appropriate users as respondents in the system evaluation process. Then the configuration is carried out on the User Experience Questionnaire (UEQ) Framework, for example: 
Each circle in the Framework User Experience Questionnaire (UEQ) form shows the measurement of the value of the system evaluation through a scale $(-3$ to +3$)$. The scale $(-3)$ indicates that the system is considered very difficult by measuring the value given by the respondent, while the scale $(+3)$ indicates that the system is really easy to understand (very pleasant). Questionnaires are given to respondents through the google form, so there will be slight changes to the question points such as the following examples and their indicators:

- Does the Student Financial ERP module in the Ministry of Finance make using the system difficult/fun?

- Does the Student Record module in the Student Service department make using the system bad/good?

- Does the Student Record module in the Student Service department make using the system slow/fast?

Table 1. UEQ Scale Indicator

\begin{tabular}{c|c}
\hline Indicator & Score \\
\hline Very Negative & -3 \\
\hline Slightly Negative & -2 \\
\hline Quite Negative & -1 \\
\hline Netral & 0 \\
\hline Slightly Positive & +1 \\
\hline Quite Positive & +2 \\
\hline Very Positive & +3 \\
\hline
\end{tabular}

The determination of the scale is carried out using the scale contained in the User Experience Questionnaire Framework so that there is no distortion of the meaning of the questions given.

\section{SPSS}

SPSS or Statistical Package for the Social Sciences is a special software that can be used to process the most widely used and popular statistical data (Zein et al., 2019). These tools are used to determine whether or not the effects on the 6 UEQ scales according to users are valid on the PeopleSoft Oracle Campus Solution ERP module (Student Record, Academic Advisement and Student Financial) through validity and reliability tests.

\section{Questionnaire Online}

This research was conducted through the distribution of online questionnaires using google form because online questionnaires are relatively simple, convenient, and easy for respondents to complete the questionnaire. Questionnaires can be statistical that can display information in the form of numbers or not numbers arranged in diagrams or tables (Adiyanta, 2019). The research was conducted through the distribution of online questionnaires using google forms to the respondents by asking about the characteristics, opinions, or behaviors that are currently happening or have already occurred. 


\section{METHODOLOGY}

\section{Sampling Technique}

In this study, non-probability sampling will be used, namely purposive sampling. This technique was chosen because the sample to be used in this study has been determined or selected through considerations that have been considered.

\section{Research Model}

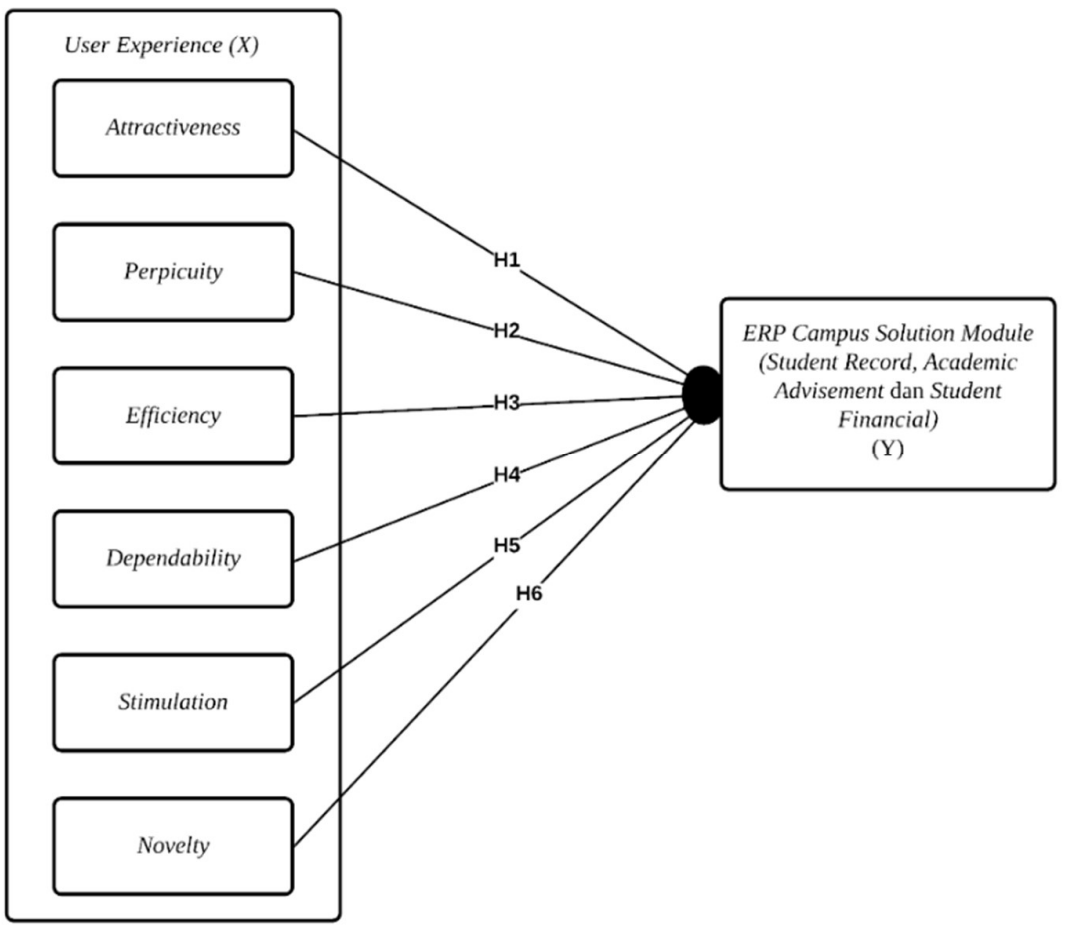

Figure 5. Research Model

Figure 5 is the research model that will be used in this study (Schrepp, 2019). The model used in this research is a quantitative descriptive research model which is a systematic study of phenomena and their causal relationships. In this research model, there are 6 aspects of measurement that can be used as hypotheses to determine the effect on user experience on the ERP module, namely:

- H1: Attractiveness has a significant effect on user experience on the ERP module.

- H2: Efficiency has a significant effect on user experience on the ERP module.

- H3: Perspicuity has a significant effect on user experience on the ERP module.

- H4: Dependability has a significant effect on user experience on the ERP module.

- H5: Stimulation has a significant effect on user experience on the ERP module.

- H6: Novelty has a significant effect on user experience on the ERP module.

The existence of the variables in Figure 5 is used to determine whether there is a significant influence between these variables on the user experience of the Campus Solution ERP system.

\section{Research Variable}


Variables can be interpreted as an indication or object that has various types of characteristics between objects with one another. There are two types of variables in this study, namely:

1. Dependent Variables are factors that are also affected due to the presence of independent variables. The dependent variable (X) in this study is the experience of users of the PeopleSoft Oracle Campus Solution ERP system at UMN with 6 UEQ scales, namely Attractiveness, Efficiency, Perspicuity, Dependability, Stimulation, and Novelty.

2. 2. Independent Variables are factors that can cause changes in the value of the dependent variable. The independent variable (Y) in this study is an indicator of 26 UEQ items in 6 UEQ scales.

\section{Data Collection Technique}

- Literature review. Conducting a literature study by collecting sources or references in the form of background data from the user experience of the PeopleSoft Oracle Campus Solution ERP system through the modules that have been used.

- Distribution of questionnaires. This stage begins with conducting questions that have been prepared, distributing online questionnaires, and collecting data from the questionnaires. In the process of preparing questions, the UEQ Framework is used which has items on a question related to the problem in this study which was carried out through an online survey (google form).

\section{Sampling Technique}

The population in this study were all the main users of the Student Record, Academic Advisement and Student Financial modules of UMN which consisted of 3 departments of UMN by calculating the sample size using the slovin formula. The samples obtained were 3 departments of UMN with 16 respondents as the main users of the module.

The distribution of online questionnaires was carried out at the Department of BIA, Student Service, and Finance of UMN within a period of 6 days starting from June 25, 2021 - June 30, 2021 with a total of 16 respondents. The selection of this module is due to the fact that there are only 3 population departments within Multimedia Nusantara University as the main users who use the module.

\section{Data Analysis Technique}

Techniques in data analysis are defined as determining the topic of the theme and conveying temporary ideas (hypotheses) formally in an effort to provide support and topics for the hypothesis (Hendri \& Setiawan, 2017). The analysis in this study uses a descriptive analysis.

The reason for choosing descriptive analysis is that it can be used in quantitative data processing where this analysis aims to systematically describe the variables being studied by collecting data from questionnaires so that they can describe quantitative data conclusions.

\section{RESULT AND DISCUSSION}

\section{Validity Test}

According to (Halin, 2018) the validity test is used to find out how far the accuracy or validity is by testing each question indicator contained in the questionnaire are:

- For questions with a correlation coefficient value $(\mathrm{r}$ count $)>(\mathrm{r}$ table $)$ it is declared valid. 
- For questions with a correlation coefficient value $(\mathrm{r}$ count $)<(\mathrm{r}$ table $)$ it is declared invalid.

Table 2. Validity Test Results

\begin{tabular}{c|c|c|c|c}
\hline Variable & Indicator & R Count & R Table & Information \\
\hline Attractiveness & AT1 & 0,682 & 0,05 & Valid \\
\cline { 2 - 5 } Aspect & AT2 & 0,711 & 0,05 & Valid \\
\cline { 2 - 5 } & AT3 & 0,673 & 0,05 & Valid \\
\cline { 2 - 5 } & AT4 & 0,692 & 0,05 & Valid \\
\cline { 2 - 5 } & AT5 & 0,669 & 0,05 & Valid \\
\cline { 2 - 5 } & AT6 & 0,710 & 0,05 & Valid \\
\hline \multirow{4}{*}{ Efficiency } & EF1 & 0,812 & 0,05 & Valid \\
\cline { 2 - 5 } & EF2 & 0,798 & 0,05 & Valid \\
\cline { 2 - 5 } & EF3 & 0,760 & 0,05 & Valid \\
\cline { 2 - 5 } & EF4 & 0,781 & 0,05 & Valid \\
\hline Perspicuity & PC1 & 0,610 & 0,05 & Valid \\
\cline { 2 - 5 } & PC2 & 0,663 & 0,05 & Valid \\
\cline { 2 - 5 } & PC3 & 0,710 & 0,05 & Valid \\
\cline { 2 - 5 } Aspect & PC4 & 0,768 & 0,05 & Valid \\
\hline & DP1 & 0,668 & 0,05 & Valid \\
\cline { 2 - 5 } & DP2 & 0,680 & 0,05 & Valid \\
\cline { 2 - 5 } & DP3 & 0,664 & 0,05 & Valid \\
\cline { 2 - 5 } & DP4 & 0,659 & 0,05 & Valid \\
\hline Stimulation & ST1 & 0,762 & 0,05 & Valid \\
\cline { 2 - 5 } Aspect & ST2 & 0,676 & 0,05 & Valid \\
\cline { 2 - 5 } & ST3 & 0,662 & 0,05 & Valid \\
\cline { 2 - 5 } & ST4 & 0,658 & 0,05 & Valid \\
\hline Novelty & NV1 & 0,647 & 0,05 & Valid \\
\cline { 2 - 5 } Aspect & NV2 & 0,655 & 0,05 & Valid \\
\cline { 2 - 5 } & NV3 & 0,671 & 0,05 & Valid \\
\cline { 2 - 5 } & NV4 & 0,658 & 0,05 & Valid \\
\hline
\end{tabular}

Table 2 the results obtained show that all variable indicators have a calculated r-value greater than the $\mathrm{r}$ table, so it can be said that all variable indicators pass the validity test that has been carried out and can be declared valid.

\section{Reliability Test}

According to (Halin, 2018) the reliability test is used to find out and carry out test measurements on the questionnaire to what extent the questionnaire can produce the same results even though repeated measurements have been made, namely:

- The criteria of data can be said to be perfectly reliable if the value of Cronbach's alpha $(\alpha)$ is 0.90 .

- The criteria for data can be said to be high reliability if the value of Cronbach's alpha $(\alpha)$ is $0.70-$ 0.90 .

- The criteria for data can be said to be moderately reliable if the value of Cronbach's alpha $(\alpha)$ is $0.50-0.70$.

- The criteria for data can be said to be of low reliability if the value of Cronbach's alpha ( $\alpha) 0.05$.

Table 3 below is a reliability test that has been carried out showing that all variable indicators have Cronbach's alpha values greater than 0.05 . So it can be concluded that all indicators of these variables are reliable and have a fairly good level of reliability. 
Table 3. Reliability Test Results

\begin{tabular}{c|c|c|c}
\hline Variable & Indicator & $\begin{array}{c}\text { Cronbach's } \\
\text { alpha }(\alpha)\end{array}$ & Information \\
\hline Attractiveness & AT1 & 0,760 & Reliabel \\
\cline { 2 - 4 } & ATpect & 0,745 & Reliabel \\
\cline { 2 - 4 } & AT3 & 0,783 & Reliabel \\
\cline { 2 - 4 } & AT4 & 0,773 & Reliabel \\
\cline { 2 - 4 } & AT5 & 0,843 & Reliabel \\
\cline { 2 - 4 } & AT6 & 0,799 & Reliabel \\
\hline \multirow{4}{*}{$\begin{array}{c}\text { Efficiency } \\
\text { Aspect }\end{array}$} & EF1 & 0,752 & Reliabel \\
\cline { 2 - 4 } & EF2 & 0,766 & Reliabel \\
\cline { 2 - 4 } & EF3 & 0,834 & Reliabel \\
\cline { 2 - 4 } & EF4 & 0,866 & Reliabel \\
\hline Asppect & PC1 & 0,744 & Reliabel \\
\cline { 2 - 4 } & PC2 & 0,865 & Reliabel \\
\cline { 2 - 4 } & PC3 & 0,788 & Reliabel \\
\cline { 2 - 4 } & PC4 & 0,744 & Reliabel \\
\hline \multirow{4}{*}{ Aspendability } & DP1 & 0,763 & Reliabel \\
\cline { 2 - 4 } & DP2 & 0,775 & Reliabel \\
\cline { 2 - 4 } & DP3 & 0,838 & Reliabel \\
\cline { 2 - 4 } & DP4 & 0,713 & Reliabel \\
\hline Stimulation & ST1 & 0,828 & Reliabel \\
\cline { 2 - 4 } Aspect & ST2 & 0,760 & Reliabel \\
\cline { 2 - 4 } & ST3 & 0,749 & Reliabel \\
\cline { 2 - 4 } & ST4 & 0,716 & Reliabel \\
\hline \multirow{4}{*}{$\begin{array}{c}\text { Novely } \\
\text { Aspect }\end{array}$} & NV1 & 0,823 & Reliabel \\
\cline { 2 - 4 } & NV2 & 0,833 & Reliabel \\
\cline { 2 - 4 } & NV3 & 0,776 & Reliabel \\
\cline { 2 - 4 } & NV4 & 0,816 & Reliabel \\
\hline
\end{tabular}

\section{Normality Test}

The normality test was carried out to determine the value of the distribution of variables or groups of data whether the data had a normal or abnormal distribution value. In testing the variables, a normality test was carried out using the One-Sample Kolmogorov-Sivnov method (Amanda et al., 2019):

- If the significance value $<0.05$, then the residual data distribution is not normal.

- If the significance value $>0.05$ then the residual data distribution is normal

Table 4. Normality Test Results

\begin{tabular}{|c|c|c|}
\hline \multicolumn{3}{|c|}{ One-Sample Kolmogorov-Smirnov Test } \\
\hline & & $\begin{array}{l}\text { Unstandardiz } \\
\text { ed Residual }\end{array}$ \\
\hline N & & 16 \\
\hline \multirow[t]{2}{*}{ Normal Parameters ${ }^{a, b}$} & Mean & .0000000 \\
\hline & Std. Deviation & 1.73869030 \\
\hline \multirow[t]{3}{*}{ Most Extreme Differences } & Absolute & .203 \\
\hline & Positive & .098 \\
\hline & Negative & -.203 \\
\hline Test Statistic & & .203 \\
\hline Asymp. Sig (2-tailed) & & $.221^{\mathrm{c}}$ \\
\hline
\end{tabular}


Table 4 measurements from the normality test, that the significance value obtained is 0.21 which means the significance value is more than 0.05 and it can be said that the regression model on that variable is normal.

\section{T-Test}

According to (As'ari, 2018) the T-test can be used to see the effect of each independent variable on the dependent variable:

- If the significance value is $<(0.05)$ then $\mathrm{H} 1$ is accepted and H0 is rejected, then what is contained in the user experience aspect of the ERP system is accepted.

- If the significance value is $>(0.05)$ then $\mathrm{H} 1$ is rejected and H0 is accepted, then what is contained in the user experience aspect of the ERP system is rejected.

\begin{tabular}{|c|c|c|c|c|c|c|}
\hline & \multicolumn{6}{|c|}{ Coefficients $^{a}$} \\
\hline \multirow[b]{2}{*}{ Model } & \multicolumn{3}{|c|}{ Unstandardized Coefficients } & \multirow{2}{*}{$\begin{array}{l}\text { Standardized } \\
\text { Coefficients } \\
\text { Beta }\end{array}$} & \multirow[b]{2}{*}{$t$} & \multirow[b]{2}{*}{ Sig. } \\
\hline & & B & Std. Error & & & \\
\hline \multirow[t]{7}{*}{1} & (Constant) & 7.122 & 14.811 & & .789 & .002 \\
\hline & Attractiveness & 1.000 & .927 & 1.233 & 1.122 & .001 \\
\hline & Efficiency & .789 & .641 & -.043 & -.541 & .003 \\
\hline & Perpicuity & 1.110 & .000 & .719 & .674 & .001 \\
\hline & Dependability & -1.133 & .819 & -.667 & .712 & .002 \\
\hline & Stimulation & .881 & .724 & -.749 & -.686 & .002 \\
\hline & Novelty & -.519 & .538 & -.462 & .587 & .003 \\
\hline
\end{tabular}

Table 5 results from the T-test on 6 aspects of the variables partially. The significance level obtained from the six aspects of the user experience variable on the use of the ERP module system is as follows:

- Attractiveness variable of $0.01<$ from 0.05 then the hypothesis is accepted.

- Efficiency variable of $0.03<$ from 0.05 then the hypothesis is accepted.

- Perspicuity variable of $0.01<$ from 0.05 then the hypothesis is accepted.

- Dependability variable of $0.02<$ from 0.05 then the hypothesis is accepted.

- Stimulation variable of $0.02<$ from 0.05 then the hypothesis is accepted.

- Novelty variable of $0.03<$ from 0.05 then the hypothesis is accepted.

\section{F-Test}

According to (Hendri \& Setiawan, 2017) the F-test can be used to test significantly whether there is an effect of the independent (free) variable simultaneously on the dependent variable:

- If the value of $F$ count $<(0.5)$ then the hypothesis contained in the user experience aspect of the ERP system is not accepted. 
- If the value of $\mathrm{F}$ count $>(0.5)$ then the hypothesis contained in the user experience aspect of the ERP system can be accepted.

Table 6. F-Test Results

ANOVA $^{\mathrm{a}}$

\begin{tabular}{|c|c|c|c|c|c|c|}
\hline Model & & $\begin{array}{l}\text { Sum of } \\
\text { Squares }\end{array}$ & df & Mean Square & $\mathrm{F}$ & Sig. \\
\hline \multirow[t]{3}{*}{1} & Regression & 51.138 & 6 & 8.523 & 2.674 & $.002^{\mathrm{b}}$ \\
\hline & Residual & 25.781 & 9 & 3.690 & & \\
\hline & Total & 51.138 & 15 & & & \\
\hline
\end{tabular}

Table 6 results from the F-test shows that the $\mathrm{F}$ table is 2.674 with a significance value of 0.02 and is smaller than alpha (0.05), then the hypothesis can be accepted. With the results obtained, it can be concluded that all user experience variables, namely Attractiveness, Perspicuity, Efficiency, Dependability, Stimulation, and Novelty have a significant influence on the use of modules in the Oracle PeopleSoft Campus Solution ERP system.

\section{Data Transformation with UEQ}

Data that has undergone data transformation will produce a grouping of average values based on a predetermined scale. The answer on a scale of -3 means agreeing with the negative terms completely (Very Negative, Slightly Negative, Moderately Negative) while 0 is Neutral and vice versa if the +3 scale means agreeing with the positive terms completely (Slightly Positive, Slightly Positive, Very Positive, Fairly Positive) (Marita, 2015).

Table 7. Rating result

\begin{tabular}{|c|c|c|c|c|c|c|c|c|c|c|c|c|c|c|c|c|c|c|c|c|c|c|c|c|c|}
\hline \multicolumn{26}{|c|}{ Items } \\
\hline 1 & 2 & 3 & 4 & 5 & 6 & 7 & 8 & 9 & 10 & 11 & 12 & 13 & 14 & 15 & 161 & 17 & 181 & 19 & 202 & 21 & 222 & 232 & $24 \quad 2$ & 252 & 26 \\
\hline 6 & 6 & 6 & 6 & 6 & 5 & 7 & 6 & 6 & 6 & 6 & 6 & 6 & 6 & 5 & 6 & 6 & 6 & 6 & 6 & 6 & 6 & 5 & 6 & 6 & 6 \\
\hline 6 & 6 & 6 & 5 & 4 & 5 & 5 & 5 & 5 & 6 & 5 & 6 & 5 & 5 & 6 & 7 & 6 & 6 & 6 & 5 & 4 & 4 & 4 & 4 & 4 & 4 \\
\hline 6 & 6 & 6 & 6 & 6 & 6 & 6 & 6 & 6 & 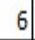 & 6 & 6 & 6 & 6 & 6 & 6 & 6 & 7 & 7 & 5 & 5 & 6 & 5 & 6 & 6 & 5 \\
\hline 6 & 7 & 6 & 6 & 6 & 6 & 5 & 5 & 6 & 6 & 6 & 6 & 6 & 6 & 6 & 6 & 6 & 5 & 6 & 6 & 6 & 6 & 5 & 5 & 6 & 6 \\
\hline 5 & 5 & 5 & 6 & 5 & 5 & 6 & 6 & 7 & 6 & 6 & 6 & 6 & 6 & 6 & 5 & 6 & 6 & 6 & 6 & 5 & 6 & 6 & 6 & 7 & 6 \\
\hline 6 & 6 & 5 & 5 & 6 & 6 & 7 & 7 & 7 & 6 & 6 & 6 & 6 & 5 & 6 & 6 & 6 & 6 & 6 & 5 & 6 & 5 & 5 & 6 & 6 & 6 \\
\hline 6 & 7 & 6 & 6 & 5 & 6 & 7 & 7 & 5 & 6 & 5 & 5 & 6 & 6 & 5 & 5 & 6 & 6 & 6 & 6 & 6 & 5 & 6 & 6 & 6 & 6 \\
\hline 5 & 6 & 5 & 5 & 5 & 6 & 7 & 6 & 6 & 6 & 7 & 6 & 6 & 6 & 6 & 6 & 6 & 5 & 6 & 6 & 6 & 6 & 5 & 5 & 6 & 5 \\
\hline 6 & 6 & 5 & 6 & 6 & 7 & 7 & 7 & 6 & 7 & 6 & 6 & 5 & 3 & 5 & 6 & 6 & 6 & 6 & 5 & 5 & 6 & 6 & 6 & 6 & 6 \\
\hline 5 & 6 & 5 & 5 & 5 & 6 & 7 & 7 & 6 & 7 & 6 & 7 & 6 & 6 & 6 & $6 \mid$ & 6 & 6 & 6 & 6 & 6 & 6 & 5 & 5 & 6 & 6 \\
\hline 6 & 6 & 5 & 5 & 5 & 5 & 6 & 6 & 6 & 7 & 5 & 6 & 6 & 5 & 5 & 5 & 6 & 5 & 6 & 5 & 5 & 5 & 6 & 6 & 6 & 6 \\
\hline 7 & 7 & 6 & 7 & 5 & 7 & 7 & 7 & 6 & 7 & 6 & 6 & 6 & 6 & 6 & 5 & 7 & 6 & 7 & 6 & 6 & 6 & 6 & 5 & 6 & 6 \\
\hline 6 & 6 & 5 & 6 & 5 & 6 & 7 & 6 & 6 & 7 & 6 & 5 & 6 & 6 & 6 & 5 & 5 & 6 & 6 & 5 & 5 & 5 & 5 & 6 & 6 & 6 \\
\hline 5 & 6 & 6 & 7 & 5 & 6 & 6 & 7 & 6 & 6 & 6 & 6 & 6 & 6 & 5 & 6 & 6 & 6 & 6 & 6 & 6 & 6 & 6 & 6 & 6 & 6 \\
\hline 5 & 6 & 5 & 5 & 5 & 6 & 6 & 6 & 5 & 6 & 5 & 6 & 5 & 6 & 5 & 5 & 6 & 6 & 6 & 6 & 6 & 6 & 5 & 6 & 6 & 5 \\
\hline 5 & 6 & 5 & 6 & 5 & 6 & 7 & 6 & 6 & 6 & 6 & 6 & 6 & 6 & 6 & 5 & 6 & 6 & 6 & 6 & 6 & 6 & 6 & 6 & & 5 \\
\hline
\end{tabular}


Table 7 is the overall result of the combined answer data from the respondents as many as 16 people who are divided into 3 departments at Universitas Multimedia Nusantara which still show a scale on the assessment of 1 to 7 .

Table 8. Appraisal Transformation

\begin{tabular}{|c|c|c|c|c|c|c|c|c|c|c|c|c|c|c|c|c|c|c|c|c|c|c|c|}
\hline & 2 & 3 & 4 & 5 & 6 & 7 & 8 & 11 & & 12 & & 14 & 15 & |16 & & 18 & 19 & & & & & 2 & 526 \\
\hline & 2 & 2 & 2 & & 1 & & & 2 & 2 & 2 & & 2 & & & & 2 & 2 & 2 & & & & & $\begin{array}{ll}2 & 2\end{array}$ \\
\hline & 2 & & & & & & & & 2 & 2 & & & 2 & & 2 & 2 & 2 & 1 & 0 & & & & $\begin{array}{lll}0 & 0\end{array}$ \\
\hline & 2 & & 2 & & 2 & & 2 & 2 & 22 & ? & & 2 & 2 & 2 & 2 & 3 & 3 & 1 & 2 & 2 & 2 & & $\begin{array}{ll}2 & 1\end{array}$ \\
\hline & 3 & 2 & 2 & & 2 & 1 & 1 & 2 & 2 & 2 & 2 & 2 & 2 & 2 & 2 & 1 & 2 & 2 & 2 & 2 & 1 & & 22 \\
\hline & 1 & 1 & 2 & 1 & 1 & 2 & 2 & 3 & 2 & 2 & 2 & 2 & 2 & 1 & 2 & 2 & 2 & 2 & 1 & 2 & 2 & 2 & $\begin{array}{ll}3 & 2\end{array}$ \\
\hline & 2 & 1 & 1 & & 2 & 3 & 3 & 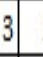 & 22 & 2 & 2 & 1 & 2 & 2 & 2 & 2 & 2 & 1 & 2 & 1 & & 2 & 22 \\
\hline & 3 & 2 & 2 & & 2 & 3 & 3 & 1 & 2. & 1 & 2 & 2 & 1 & 1 & 2 & 2 & 2 & 2 & 2 & 1 & & 2 & 22 \\
\hline & 2 & 1 & 1 & & 2 & 3 & 2 & 2 & 23 & 3 & 2 & 2 & 2 & 2 & 2 & 1 & 2 & 2 & 2 & 4 & 1 & 1 & 21 \\
\hline & 2 & 1 & 2 & & 3 & 3 & 3 & 2 & 3 & 2 & 1 & 1 & 1 & 2 & 2 & 2 & 2 & 1 & 1 & 2 & 2 & 2 & 22 \\
\hline & 2 & 1 & 1 & 1 & 2 & 3 & 3 & 2 & 3 & 2 & 2 & 2 & 2 & 2 & 2 & 2 & 2 & 2 & 2 & 2 & 1 & 2 & 22 \\
\hline & 2 & 1 & 1 & 1 & 1 & 2 & 2 & & & 1 & 2 & 1 & 1 & 1 & 2 & 1 & 2 & 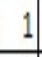 & 1 & 1 & 2 & 2 & 22 \\
\hline & 3 & 2 & 3 & & 3 & 3 & 3 & & & 2 & 2 & 2 & 2 & 1 & 3 & 2 & 3 & 2 & 2 & 2 & 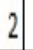 & . & 22 \\
\hline & 2 & 1 & 2 & & 2 & 3 & 2 & 2 & & 2 & 2 & 2 & 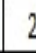 & 1 & 1 & 2 & 2 & 1 & 1 & 1 & 1 & 2 & 22 \\
\hline & 2 & 2 & 3 & & 2 & 2 & 3 & 2 & & 2 & 2 & 2 & 1 & 2 & 2 & 2 & 2 & 2 & 2 & 2 & & 2 & 22 \\
\hline & 2 & & 1 & & 2 & 2 & 2 & & & 1 & & 2 & 1 & 1 & 2 & 2 & 2 & 2 & 2 & 2 & & 2 & $\begin{array}{ll}2 & 1\end{array}$ \\
\hline & & & & & & & & & & & 2 & & & & 2 & 2 & & 2 & & & & & $\begin{array}{ll}2 & 1\end{array}$ \\
\hline
\end{tabular}

Table 8 is the result of the transformation of the combined assessment of each respondent that has been collected from 3 Departments at UMN in accordance with the order of values that have been randomized in the questionnaire to minimize any tendency in the answers.

Answers with a scale of -2 which means completely agree with the negative terms while +3 which means completely agree with the positive terms. Half of the answer items started with a positive term while the other half started with a negative term (random order).

\section{Main Results}

Result is the main result of UEQ processing which will be a reference for the next calculation, namely the Benchmark Data Set.

The determination of the mean (mean) has a standard data impression, which is between -0.8 and 0.8 is normal, while $>0.8$ is an evaluation of a positive value and $<-0.8$ is an evaluation of a negative value (Schrepp et al., 2017). 
Table 9. The Mean, Variance, and Standard Deviation

\begin{tabular}{|c|c|c|c|c|c|c|c|}
\hline Item | & Mean & Variance & Std. Dev. & No. & Left & Right & Scale \\
\hline 1 & १ 1.7 & 0.4 & 0.6 & 16 & annoying & enjoyable & Attractiveness \\
\hline 2 & 令 2.1 & 0.3 & 0.5 & 16 & not understandable & understandable & Perspicuity \\
\hline 3 & ค 1.4 & 0.3 & 0.5 & 16 & creative & dull & Novelty \\
\hline 4 & 而 1.8 & 0.5 & 0.7 & 16 & easy to learn & difficult to learn & Perspicuity \\
\hline 5 & 令 1.3 & 0.3 & 0.6 & 16 & valuable & inferior & Stimulation \\
\hline 6 & 令 1.9 & 0.4 & 0.6 & 16 & boring & exciting & Stimulation \\
\hline 7 & 会 2.4 & 0.5 & 0.7 & 16 & not interesting & interesting & \begin{tabular}{|l|} 
Stimulation \\
\end{tabular} \\
\hline 8 & 令 2.3 & 0.5 & 0.7 & 16 & unpredictable & predictable & Dependability \\
\hline 9 & 令 2.0 & 0.3 & 0.5 & 16 & fast & slow & Efficiency \\
\hline 10 & 令 2.3 & 0.2 & 0.5 & 16 & inventive & conventional & Novelty \\
\hline 11 & 令 1.8 & 0.3 & 0.5 & 16 & obstructive & supportive & Dependability \\
\hline 12 & १ 1.9 & 0.2 & 0.4 & 16 & good & bad & Attractiveness \\
\hline 13 & 令 1.8 & 0.2 & 0.4 & 16 & complicated & easy & Perspicuity \\
\hline 14 & 令 1.8 & 0.2 & 0.4 & 16 & unlikable & pleasing & Attractiveness \\
\hline 15 & 巾 1.6 & 0.3 & 0.5 & 16 & usual & leading edge & Novelty \\
\hline 16 & 令 1.6 & 0.4 & 0.6 & 16 & unpleasant & pleasant & Attractiveness \\
\hline 17 & 令 2.0 & 0.1 & 0.4 & 16 & secure & not secure & Dependability \\
\hline 18 & 令 1.9 & 0.3 & 0.5 & 16 & motivating & demotivating & Stimulation \\
\hline 19 & १ 2.1 & 0.1 & 0.3 & 16 & meets expectations & does not meet expectations & Dependability \\
\hline 20 & 令 1.6 & 0.3 & 0.5 & 16 & inefficient & efficient & Efficiency \\
\hline 21 & 令 1.6 & 0.4 & 0.6 & 16 & clear & confusing & Perspicuity \\
\hline 22 & 用 1.6 & 0.4 & 0.6 & 16 & impractical & practical & Efficiency \\
\hline 23 & 令 1.5 & 0.4 & 0.6 & 16 & organized & cluttered & Efficiency \\
\hline 24 & 令 1.6 & 0.4 & 0.6 & 16 & attractive & unattractive & Attractiveness \\
\hline 25 & १ 1.9 & 0.3 & 0.6 & 16 & friendly & unfriendly & Attractiveness \\
\hline 26 & 令 1.6 & 0.4 & 0.6 & 16 & conservative & innovative & Novelty \\
\hline
\end{tabular}

Table 9 calculates the average, variance, and standard deviation for each of the answer items. The items contained in the UEQ questions consist of 26 question items that can be seen on the right and left as a benchmark for the weight of the question and produce answers from respondents to the specified scale. The explanation of table headers from left to right is as follows:

- Headers on the mean. The up arrow means that the standard impression value (influence) of the question item is positive $(>0.8)$.

- Variance is the value of the distribution between numbers in the data set (the average value).

- Standard deviation is a measure of the number of variations of a set of values. If the value at the standard deviation is low, it indicates that the value will tend to approach the mean, while if the value at the standard deviation is high, it indicates that the value is spread over a wider range.

- The color right part is the grouping of question items based on their indicators:

$\circ$ The indicator in the Attractiveness question is purple.

- The indicator in the Efficiency question is sky blue.

- The indicator in the Perspicuity question is green.

$\circ$ The indicator in the Dependability question is a pale turquoise color.

$\circ$ The indicator in the Stimulation question is a red heart.

$\circ$ The indicator in Novelty's question is orange

Table 10. UEQ Mean and Variant Results

\begin{tabular}{|l|l|r|}
\hline \multicolumn{3}{|c|}{ UEQ Scales (Mean and Variance) } \\
\hline Attractiveness & 1.760 & 0.03 \\
\hline Perspicuity & 个 1.828 & 0.15 \\
\hline Efficiency & 个 1.688 & 0.13 \\
\hline Dependability & 个 2.047 & 0.09 \\
\hline Stimulation & 个 1.859 & 0.16 \\
\hline Novelty & 个 1.750 & 0.06 \\
\hline
\end{tabular}


Table 10 is the result of the average question items that have been obtained and can be concluded as follows:

- Attractiveness has an average value of 1.760 (positive impression standard >0.8) and a standard deviation of 0.03 .

- Perspicuity has an average value of 1.828 (positive impression standard $>0.8$ ) and a standard deviation of 0.15 .

- Efficiency has an average value of 1.688 (positive impression standard $>0.8$ ) and a standard deviation of 0.13 .

- Dependability has an average value of 2.047 (positive impression standard $>0.8$ ) and a standard deviation of 0.09 .

- Stimulation has an average value of 1.859 (positive impression standard $>0.8$ ) and a standard deviation of 0.16 .

- Novelty has an average value of 1.750 (positive impression standard $>0.8$ ) and a standard deviation of 0.06 .

\section{UEQ Benchmark Dataset}

The User Experience Questionnaire uses a special standard, namely Benchmarks that can be used to describe the comparison of levels in aspects of Attractiveness, Perspicuity, Efficiency, Dependability, Stimulation and Novelty (Suastini, Ni Komang Lanang, I Gusti Satwika, 2018). The comparative values in the six aspects are classified into five categories, namely:

1. Excellent the mean result $>1.75$

2. Good the mean result $>1.52$

3. Above Average the mean result $>1.171$

4. Below Average the mean result $>0.7$

5. Bad the mean result $<0.7$

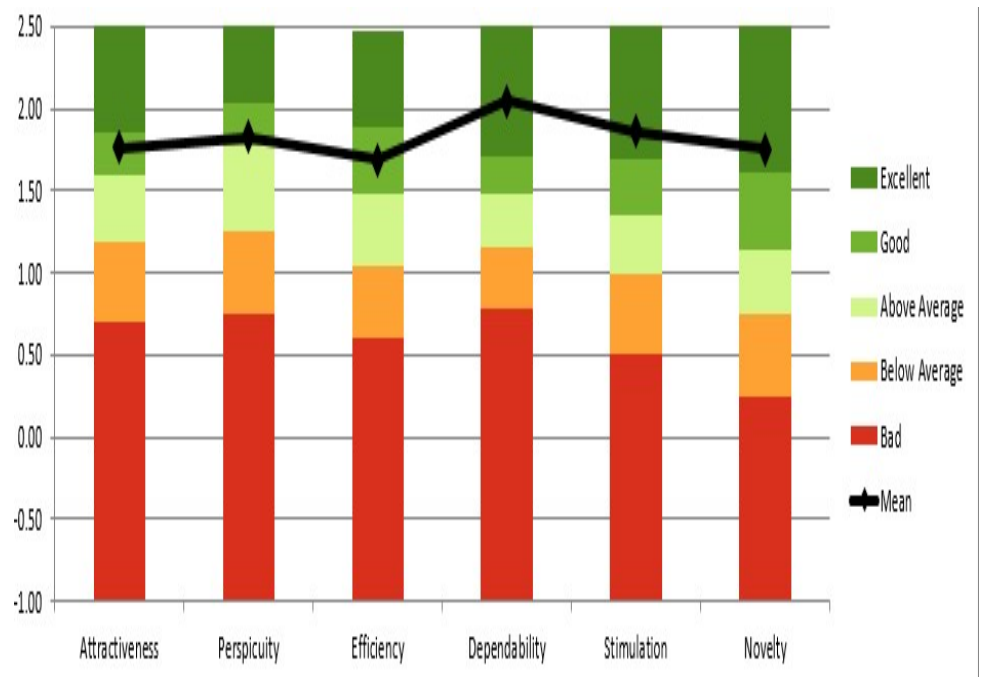

Figure 6. Benchmark Level Visualization 
Figure 6 shows the results of the comparison of visualizations that have been obtained for the six aspects of Attractiveness, Perspicuity, Efficiency, Dependability, Stimulation, and Novelty, namely:

- Attractiveness, Perspicuity, and Efficiency show that the range of values is at 1.83 to 1.69 which means that from the three aspects the average value can be included in the Good category.

- Dependability, Stimulation, and Novelty. shows the level of the value range is from 2.05 to 1.86 which can be interpreted that from both aspects the average value can be included in the Excellent category.

It can be concluded that the graphs on the six aspects of user experience on the use of ERP system modules tend to have a positive impression (the value is in the direction of 1.83), respectively:

1. Dependability.

2. Stimulation.

3. Perspicuity.

4. Attractiveness.

5. Novelty.

6. Efficiency.

\section{CONCLUSION}

Based on the discussion and results of data analysis that has been obtained using the Framework User Experience Questionnaire and Multiple Linear Regression using SPSS software version 25, there is a significant influence between the variables of the six aspects of Attractiveness, Perspicuity, Efficiency, Dependability, Stimulation, and Novelty. against users of the ERP PeopleSoft Oracle Campus Solution module for Student Record, Academic Advisement and Student Financial modules at Multimedia Nusantara University had the following results:

1. Based on the results of the t-test, f-test and normality, it can be concluded that the aspect variables in the UEQ are Attractiveness, Perspicuity, Efficiency, Dependability, Stimulation, and Novelty partially or completely can have a significant $61 \%$ influence on the use of modules in the system ERP at Universitas Multimedia Nusantara.

2. The results of the measurement level based on the mean and benchmark user experience data in terms of Attractiveness, Perspicuity, Efficiency, Dependability, Stimulation, and Novelty for users of the ERP PeopleSoft Oracle Campus Solution module Student Record, Academic Advisement, and Student Financial modules can start from the highest value to lowest as follows:

1) Dependability with the overall mean value is 2.05 (Excellent).

2) 2) Stimulation with the overall mean value is 1.86 (Excellent).

3) 3) Novelty with an overall mean score of 1.83 (Excellent).

4) 4) Perspicuity with the overall mean value is 1.76 (Good).

5) 5) Attractiveness with the overall mean value is 1.75 (Good).

6) 6) Efficiency with the overall mean value is 1.69 (Good). 


\section{JOURNAL OF MULTIDISCIPLINARY ISSUES}

Journal Website: www.jmis.site

J. Multi. Discp. Issues 1(2) 42-61 (2021)

\section{REFERENCES}

Adiyanta, F. C. S. (2019). Hukum dan Studi Penelitian Empiris: Penggunaan Metode Survey sebagai Instrumen Penelitian Hukum Empiris. Administrative Law and Governance Journal, 2(4), 697-709. https://doi.org/10.14710/alj.v2i4.697-709

Amanda, L., Yanuar, F., \& Devianto, D. (2019). Uji Validitas dan Reliabilitas Tingkat Partisipasi Politik $\begin{array}{llllll}\text { Masyarakat Kota Padang. Jurnal Matematika UNAND, } & 8(1),\end{array}$ https://doi.org/10.25077/jmu.8.1.179-188.2019

As'ari, R. (2018). Pengetahuan dan Sikap Masyarakat dalam Melestarikan Lingkungan Hubungannya dengan Perilaku Menjaga Kelestarian Kawasan Bukit Sepuluh Ribu di Kota Tasikmalaya. Jurnal GeoEco, 4(1), 9-18.

Bruun, A., \& Stage, J. (2015). An empirical study of the effects of three think-aloud protocols on identification of usability problems. Lecture Notes in Computer Science (Including Subseries Lecture Notes in Artificial Intelligence and Lecture Notes in Bioinformatics), 9297, 159-176. https://doi.org/10.1007/978-3-319-22668-2_14

Dewi, P. P., \& Asriani, N. L. P. (2019). Analisis Faktor-Faktor Kesuksesan Penerapan Enterprise Resource Planning (ERP) Pada Perusahaan Pengguna ERP Wilayah Bali. Jurnal Riset Akuntansi Mercu Buana, 5(1), 39. https://doi.org/10.26486/jramb.v5i1.645

Farida, L. D. (2016). Pengukuran User Experience Dengan Pendekatan Usability [Kasus: Website Pariwisata Di Asia Tenggara]. Seminar Nasional Teknologi Informasi Dan Multimedia, 6-7.

Halin, H. (2018). EcoMent Global 167. Hamid Halin, 3, 167-182.

Hendradewa, A. P. (2017). Perbandingan metode evaluasi. Perbandingan Metode Evaluasi Usability (Studi Kasus : Penggunaan Perangkat Smartphone), 23(1), 9-18. http://journal.uii.ac.id/index.php/jurnalteknoin/article/viewFile/8332/7102

Hendri, \& Setiawan, R. (2017). Pengaruh Motivasi Kerja dan Kompensasi Terhadap Kinerja Karyawan di PT. Samudra Bahari Utama. Jurnal AGORA, 5(1), 1-8.

Jacobs, F. R., \& Weston, F. C. T. (2007). Enterprise resource planning ( ERP )—A brief history. 25, 357359. https://doi.org/10.1016/j.jom.2006.11.005

James A. O’Brien, G. M. M. (2007). Management Information Systems (p. 3005).

Kulathunga, D., \& Krishantha, M. (2019). User Satisfaction Factors of ERP Systems: The Case of a Manufacturing Company in Sri Lanka. European Journal of Business and Management, 11(33), 105114. https://doi.org/10.7176/ejbm/11-33-12

Laugwitz, B., Held, T., \& Schrepp, M. (2008). Construction and evaluation of a user experience questionnaire. Lecture Notes in Computer Science (Including Subseries Lecture Notes in Artificial Intelligence and Lecture Notes in Bioinformatics), 5298 LNCS, 63-76. https://doi.org/10.1007/978-3540-89350-9-6

Marita, W. E. (2015). Pengaruh Struktur Organisasi dan Ukuran Perusahaan Terhadap Penerapan Business Entity Concept. AKRUAL: Jurnal Akuntansi, 7(1), 18. https://doi.org/10.26740/jaj.v7n1.p18-40

O'Regan, G. (2015). Oracle Corporation. Pillars of Computing, 163-169. https://doi.org/10.1007/978-3319-21464-1_25

Oracle PeopleSoft. (2015). PeopleSoft Campus Solutions 9 . 2: Academic Advisement. December. $\mathrm{http} / / /$ docs.oracle.com/cd/E68290_01/psft/acrobat/cs921ssr-b1215.pdf

Oracle PeopleSoft. (2015). PeopleSoft Campus Solutions 9.2: Campus Community. December. http://docs.oracle.com/cd/E68290_01/psft/acrobat/cs921ssr-b1215.pdf

Oracle PeopleSoft. (2015). PeopleSoft Campus Solutions 9 . 2: Contributor Relations. December. http://docs.oracle.com/cd/E68290_01/psft/acrobat/cs921ssr-b1215.pdf

Oracle PeopleSoft. (2015). People $\bar{S}$ oft Campus Solutions 9 . 2: Financial Aid. December. http://docs.oracle.com/cd/E68290_01/psft/acrobat/cs921ssr-b1215.pdf

Oracle PeopleSoft. (2015). PeopleSoft Campus Solutions 9 . 2: Gradebook. December. http://docs.oracle.com/cd/E68290_01/psft/acrobat/cs921ssr-b1215.pdf

Oracle PeopleSoft. (2015). PeopleSoft Campus Solutions 9 . 2: Student Financial. December. http://docs.oracle.com/cd/E68290_01/psft/acrobat/cs921ssr-b1215.pdf

Oracle PeopleSoft. (2015). PeopleSoft Campus Solutions 9 . 2: Student Records. December. 
http://docs.oracle.com/cd/E68290_01/psft/acrobat/cs921ssr-b1215.pdf

Panorama Consulting Solutions. (2019). 2019 ERP Report: People | Process | Technology. https://cdn2.hubspot.net/hubfs/4439340/2019-ERP-Report-3.pdf

PeopleSoft. (2012). PeopleSoft Campus Solutions : Innovating for the Global Campus.

PeopleSoft Campus Solutions 9 . 0: Recruiting and Admissions. (2014). September.

RAJESH KUMAR. (2019). Wealth Creation in the World's Largest Mergers and Acquisitions. Book, 359. https://doi.org/10.1007/978-3-030-02363-8

Schrepp, M. (2019). User Experience Questionnaire Handbook Version 8. URL: Https://Www. Researchgate.

Net/Publication/303880829_User_Experience_Questionnaire_Handbook_Version_2.(Accessed: 02.02. 2017), 1-15.

Schrepp, M., Hinderks, A., \& Thomaschewski, J. (2017). Construction of a Benchmark for the User Experience Questionnaire (UEQ). International Journal of Interactive Multimedia and Artificial Intelligence, 4(4), 40. https://doi.org/10.9781/ijimai.2017.445

Service, S. (2021). PeopleSoft Campus Solutions 9.2: Self Service. February.

Suastini, Ni Komang Lanang, I Gusti Satwika, I. P. (2018). Analisis Pengalaman Pengguna Pada Website Distro Management System ( Dimans ). Jurnal Ilmiah Teknik Informatika Dan Sistem Informasi, 7(3), 135-144. http://ojs.stmik-banjarbaru.ac.id/index.php/jutisi/article/view/300/284

Wallace, T. F., \& Kremzar, M. H. (2001). AM ERP : Making It Happen Resource Planning. In New York. http://cyberrvr.weebly.com/uploads/5/9/7/8/5978545/wiley___erp_making_it_happen.pdf

Zein, S., Yasyifa, L., Ghozi, R., Harahap, E., Badruzzaman, F., \& Darmawan, D. (2019). Pengolahan dan Analisis Data Kuantitatif Menggunakan Aplikasi SPSS. Jurnal Teknologi Pendidikan Dan Pembelajaran, 4(1), 1-7. 